\title{
Telemedicine and telehealth: an Italian and UK perspective
}

\section{Massimo Capoccia, MD, MSc 1,2, Claudio De Lazzari ${ }^{3,4}$, Domenico M. Pisanelli 5, Beatrice De Lazzari ${ }^{6}$}

\author{
${ }^{1}$ Royal Brompton Hospital, Royal Brompton \& Harefield NHS Foundation Trust, UK \\ ${ }^{2}$ Department of Biomedical Engineering, University of Strathclyde, Glasgow, UK \\ capoccia@doctors.org.uk \\ ${ }^{3}$ National Research Council, Institute of Clinical Physiology (IFC-CNR), Rome, Italy \\ ${ }^{4}$ Teaching University Geomedi, Tbilisi, Georgia, claudio.delazzari@ifc.cnr.it \\ ${ }^{5}$ National Research Council, Institute of Cognitive Sciences and Technologies, Rome, Italy \\ domenico.pisanelli@cnr.it \\ "Foro Italico" 4th University of Rome, Italy, beatrice.delazzari@gmail.com \\ Corresponding Author: Prof. Claudio De Lazzari, C.N.R., Institute of Clinical Physiology, \\ U.O.S. of Rome, Italy, Via Palestro 32, 44, 00185 Rome, Italy \\ Fax:+390649936299Ｅ-mail: claudio.delazzari@ifc.cnr.it
}

\begin{abstract}
\section{Background}

On January 30, 2020, the Director-General of the World Health Organization (WHO) declared the international outbreak of new coronavirus 2019-nCoV (Public Health Emergency of International Concern -PHEIC), as enshrined in the International Health Regulations (IHR, 2005).
\end{abstract}

The current pandemic has uncovered our vulnerability and fears turning our lives upside down.

We have been forced to a more resourceful approach with a view to contain and limit potential damage.

The current events have put significant strain on hospital organisations all over the world.

\section{Objective}

At a time when, in the absence of specific therapy to treatcardio patients and a vaccine only recently approved, social distancing is one of the main measures used to combat the COVID-19 pandemic, telemedicine is gaining ground as a key technology for safe and efficient communication between doctors and patients.

The aim is to highlight the major role played by telemedicine and telehealth during the pandemic with reference to the potential implications for the foreseeable future.

\section{Methods}

We have attempted to give a survey on telemedicine and telehealth applications in Italy and UK before and during the management of the pandemic. 


\section{Results}

Some examples of the application of telemedicine and telehealth with reference to their impact and relationship with end users have been highlighted.

\section{Conclusion}

Telemedicine and telehealth are likely to become more established in the future. We may have to reconsider our current working patterns towards a more beneficial and cost-effective way of living and working.

Key words: Telemedicine, Telehealth, COVID-19, Cardiovascular Disease.

\section{Introduction}

The world is on its knees. This is the utter reality and it would be foolish to deny it.

The recent events have confirmed how vulnerable and unprepared we are to face a viral illness that is claiming thousands of lives despite our highly advanced level of technology and knowledge.

Our daily activities and jobs have been suddenly forced to a complete rearrangement. Small and large businesses forced to stop. Whole countries in lockdown in an attempt to slow down and contain an invisible killer we do not know much about. Hospitals, GP surgeries and other primary care centres have been forced to redirect the available resources to fight against the new "black death". Those who have read "The Betrothed" by Alessandro Manzoni may well understand the similarities.

In a matter of days, we have witnessed a complete revolution in telemedicine in Europe and the United States.

The World Health Organization (WHO) itself has mentioned telemedicine as one of the essential services in its policy of "strengthening the response of health systems to COVID-19" [1]. According to a new WHO policy, as part of the action to optimise service delivery, telemedicine should be one of the alternative models for clinical services and clinical decision support. However, it should be noted that telemedicine does not replace traditional medicine but supports and integrates it with new communication channels and innovative technologies, with the aim to improve healthcare and help patients access and obtain the best possible care.

Despite the initial scepticism, virtual consultations have become the "new normal" in order to maintain social distancing but at the same time to keep tracking of those patients in need because of other diseases. With fears running high, there is a need to treat anyone who can afford to remain at home with a video session or a phone call. The strict rules about privacy and data protection had to be reviewed in response to the pandemic. Microsoft Teams has soon become the virtual communication system for clinicians during Covid-19 pandemic in relation to hand-over between shifts, MDT meetings for decision-making and communication between "dirty" and 
"clean" areas. Nevertheless, face-to-face contact has been maintained whenever required in the context of social distance measures.

Although all this is happening in the heat of the moment, concerns remain about the limitations related to patient examination, potential for missing diagnosis and allocation of resources.

\section{Material and Methods}

To avoid confusion is important to understand the meaning of telehealthcare and telemedicine, which are often misleading because used without clear boundaries.

Telehealth is a collection of means or methods for the enhancement of health care, public health and health education delivery and support the use of telecommunications technologies.

Telehealth encompasses a broad variety of technologies and tactics to deliver virtual medical, health, and education services. Telehealth is not a specific service but a collection of means to enhance care and education delivery.

Telehealth is different from telemedicine in that it refers to a broader scope of remote healthcare services than telemedicine. Telemedicine refers specifically to remote clinical services, while telehealth can refer to remote non-clinical services.

Telehealth is personalised treatment delivered over a distance with data transfer between patient and medical professional, who gives advice after review. Chronic conditions like asthma/COPD, diabetes and hypertension may well be suitable for this approach, which reduces travelling to hospital and saves time. The disadvantage is a breakdown in patient/healthcare professional relationship although the problem may also arise from poor interpersonal skills and/or poor mastery of the technology used. Nevertheless, a new referral would still require a traditional faceto face appointment at the beginning for a thorough clinical examination and timely discussion $[2,3]$.

Telemedicine is mainly related to information sharing between clinicians or hospitals over a distance [3]. For example, MDT meetings with imaging review and discussion for decisionmaking between referring and treating clinician; continuing medical education programmes; distant training and simulation with exchange of experience between groups of professionals. Another aspect currently not being addressed is the potential of telemedicine during earthquakes or flooding as a more direct interaction between rescuers on site and hospital specialists in relation to triage and advice.

Healthcare systems worldwide are facing significant challenges in the context of an aging population with an increasing number of chronic conditions, increasing expectations and difficulty with healthcare delivery in remote areas and resource availability. Telemedicine and telehealthcare may offer a solution to these problems but acceptance, effectiveness and safety must be taken into account. The evidence for cost-effectiveness remains limited at present [3-5] although a more recent analysis highlights the genuine potential for cost-effectiveness [6]. 
The OECD (Organisation for Economic Co-operation and Development) states that telemedicine may be divided into three categories and combined as appropriate (see [7] for major details):

1) Remote monitoring, i.e. employing mobile devices in order to carry out routinary tests and make results available to healthcare professionals in real time.

2) Storage and forwarding applications. They are comparable to the previous category although they are employed for those kind of data, which does not require a short time between transmission and answer.

3) Real time interactive telemedicine. In such a case HC professionals and patients need real time communication.

We have sought to give an overview of this approach and make some considerations about pros and cons.

\section{Results}

There are examples of how telemedicine and telehealth have been applied with reference to their impact and relationship with end users. Telemedicine and telehealth have played a major role during the pandemic with reference to the potential implications for the foreseeable future. The current events may have fast-forwarded a process that had already started at slow pace but without clear direction.

The introduction of telemedicine and telehealthcare in the UK has been slow in view of political, organisational and safety issues although a recent national strategy has addressed this aspect of healthcare delivery for the immediate future $[5,8,9]$. The UK has seen a rapid growth in telemedicine in the last years. A significant amount of funding has been allocated to many different programs devoted to research and application in universities, hospitals, and health institutes (see [10]). The Royal Society of Medicine in London is the main medical organization supporting these developments through its Telemedicine Forum with meetings, conferences (annual Telemed conferences), and publications (Journal of Telemedicine and Telecare) [11]. As reported in [techweb], other more recent professional organizations, such as TEAM (Toward Education for ALL with Multimedia), are contributing to global collaboration in clinical care, telemedicine teaching and research with the provision of global health education using all forms of information technologies, such as the World Wide Web and teleconferencing.

An example of established telemedicine in the UK is based at Airedale NHS Foundation Trust in West Yorkshire, which provides a unique range of digital healthcare solutions developed by close cooperation between clinicians and patients. There has been a true commitment to fully understand patients' needs and continue to improve the quality and safety of patients' experience. The telemedicine service is delivered through the Digital Care Hub. Such a hub was established in 2011, becoming immediately leader in UK by offering "a single point of access to expert clinical 
and social assessment, diagnosis, advice and support through a 24/7 system operating 365 days per year." [12].

The service employs a multidisciplinary team with different backgrounds. The variety of available skills is a relevant asset to be considered, together with the experience and the high training level of the different professionals involved.

The service branches out in three key directions.

The first one is the "Goldline", available $24 / 7$ by telephone. It is provided by nurses and it is devoted to terminal patients - mainly at home - and their caregivers.

The "Careline" provides telemedicine support to people restricted to prisons and youth offender institutions.

"Immedicare" is a telemedicine service regarding chronic patients and over 500 residential and nursing homes (see [12] for more details).

Italy has an earlier history of telemedicine applications [13]. The first example was in the early Seventies when one of the main University Hospitals in Rome established a telephone service providing teleconsulting for the treatment of poisonous intoxications. Initially run on a local network area, the service is nowadays available all over Italy.

In 1976, Bologna University developed a prototype aimed at acquiring and transmitting ECG by phone.

Also in this year, CSELT in Turin set up an experimental service of teleconsulting between two hospitals of the Piedmont region: San Giovanni in Turin and Susa in the province.

In 1982, the Italian government acknowledged the strategic relevance of telemedicine and its potentialities for Health Care improving and cost reductions. The role of telemedicine as a research tool in medical informatics with a view to enhance diagnosis and treatment was also emphasized.

In the late Eighties the Ministry conceived a "National plan for research and training in telemedicine" [13] with funding up to 100 billion lira (50 million Euros).

Despite these early and promising applications, the use of telemedicine has not lived up to its expectations with unmet needs. Nevertheless, the pandemic has witnessed a surge of this approach by necessity but also the need for appropriate guidelines for its use, which may be instrumental for the National Health System if adequately funded. Conversely, the Italian Armed Forces has implemented military telemedicine systems for both military operations and humanitarian missions, while the Civil Defence has developed telemedicine models to manage emergencies and catastrophes.

"Innova Italia" is a recent initiative promoted by the Ministry of Economic Development, the Ministry of University and Research, the Ministry for Technological Innovation and Digitization and the Ministry of Health. A total of 504 proposals of digital solutions for the remote 
management of patients suffering from COVID-19 and/or other chronic diseases have been submitted and reviewed by a ministerial commission with the selection of five best apps and technical remote assistance solutions (Table 1), for active patients' surveillance at home during isolation for suspected or confirmed COVID-19 diagnosis.

\begin{tabular}{|l|l|}
\hline \multicolumn{2}{|c|}{ Table 1 } \\
\hline Solution & \multicolumn{1}{c|}{ Proponent } \\
\hline Co4Covid-19 & Dedalus Italia S.p.A. \\
\hline Smart Axistance Covid-19 Control & ENEL X Italia in costituendo RTI \\
\hline eLifeCare Covid-19 & Exprivia S.p.A. \\
\hline LazioDoctor & LAZIOcrea S.p.A. \\
\hline Ticuro Reply & REPLY S.p.A. \\
\hline
\end{tabular}

"Co4Covid-19" is a responsive web-app made available to individuals to complete both a pretriage questionnaire and clinical self-assessment in the quarantine or self-isolation phase. There is a system for television, including psychological assessment, and tele-monitoring, which includes clinical and environmental sensor kits, chat-box, tutorial, reminder, diary, info, exams. All information is collected in a clinical repository and made available to the operations centre.

"Smart Axistance Covid-19 Control" is a CE/MED certified telemedicine platform registered with the Ministry of Health and available to public health facilities and General Practitioners to monitor the health status of individual patients and their relatives. Remote monitoring consists of a series of vital parameters, both for the management of COVID -19 and chronic diseases. "ASL Roma 2" has used this system for more than a year for chronic diseases.

The "eLifeCcare Covid-19" telemedicine platform is specifically configured for remote assistance of COVD-19 patients. It is aimed at COVID-19 patients during home isolation / quarantine. Key parameters such as body temperature, saturation and heartbeat are monitored and acted upon if clinical conditions deteriorate.

"LazioDoctor" gives quick and safe access to health care services in the event of a suspected infection and, if positive, the subsequent management of the entire cycle of care is remotely provided by GPs, primary care organizations and specialists. The app allows data collection to monitor the health status of patients in isolation, who have tested positive or have come into contact with positive patients.

"Ticuro Reply" allows automatic and manual collection of parameters that feed a clinical diary, which can be accessed regularly for monitoring and treatment. Alarms are automatically generated if the values are outside the target range. With "Televisita" a direct audio/video/chat contact with a doctor is available to share documents and access the clinical diary with a view to treatment plan supported by interactive questionnaires and video tutorials. 


\section{Discussion and future prospects}

Telemedicine is giving a significant contribution to healthcare professionals during the current pandemic although certain limitations remain and must be acknowledged. There is a chance that telemedicine may contribute to hospitals being overwhelmed if used inappropriately, though we are learning to adapt accordingly.

The ability to screen patients remotely enables the triage of those who do not need immediate medical intervention and can receive care at home. This helps lower the risk of transmitting the infection to other patients and healthcare staff. At the same time, care can be provided for those patients with chronic diseases who are at risk if exposed to the virus. Finally, healthcare professionals who are self-isolating or in quarantine because tested positive can still provide remote care for patients if needed [14]. Nevertheless, this approach may need modification to help manage early testing, diagnosis and admit those patients who require in-hospital treatment. All this sounds really great but the reality is different considering that telemedicine has not been used traditionally in response to public health major events. Therefore, many hospitals and GP surgery are not completely fit for purpose. There is a learning curve for the use of telemedicine in the traditional patient/doctor relationship. A telephone call remains at present the way to notify patients about rescheduling of appointments with remote consultation.

Most hospitals operate at full or near full capacity, therefore telemedicine may well be the way forward to relieve additional burden provided it is implemented appropriately.

Hospitals usually prepare for adverse events or crises like winter flu but telemedicine is not something we are accustomed to. The recent events are forcing more and more hospitals to use this type of technology for patients' follow-up and adapt to a certain extent as far as training is concerned.

Telemedicine is not a new concept and has been previously considered [15-17] but its implementation has been slow and difficult to take off [4].

There is no question about the potential benefit of telemedicine in relation to access to quality healthcare for rural communities, monitoring of long-term conditions from a distance, offer of effective advice and enhanced communication between healthcare professionals and relatives $[2,18]$. This is very attractive for patients who are willing to accept telemedicine as an additional tool $[4,17]$. What about the healthcare professionals? The key points are the perceived usefulness, the perceived ease-of-use and the intention to use [4]. This is quite an important aspect highlighting the need to consider telemedicine for those patients who would benefit the most and avoid its regular use $[3,19]$.

The attitude towards telemedicine and telehealthcare is changing and the current pandemic (COVID-19) is a clear example. Nevertheless, the effective and safe implementation of this type of technology in NHS Trusts must be clear since the beginning to avoid disappointment and in line with the available resources. Aims like access improvement to available facilities, increased 
satisfaction and avoidance of emergency admissions based on close monitoring and cost reduction may be justified as long as safety is not compromised in the absence of face-to-face consultations. Type of disease, type of technology, age of patients and their ability to interact with technology and also clinicians' expertise and ability to interact with technology should be considered. Finally, cost-benefit evaluation remains a limiting factor in the context of ongoing limited funding availability.

Another important issue is the shared decision making process, which is highly dependent on clear, honest and unhurried communication. This is essential to patient-centred care but how to best implement it remains unknown. Would a shift toward telehealth reduce or increase healthcare disparities? There is evidence to suggest that a trusting relationship with shared decision-making can be achieved over a telephone consultation although this precludes the use of additional material or behavioural attitude that can be achieved in an in-person consultation. Videoconferencing technology may well help to overcome this barrier. Nevertheless, potential disparities introduced by telehealth are likely to be related to age, digital readiness, income, level of education and race [20]. The resurgence of telemedicine has to be acknowledged but there has to be a commitment to realise its full potential taking into account its advantages and limitations [21-24].

The economic burden to develop and run a national Tele-health network cannot be compared to the efforts required to face a serious environmental adverse event. The COVID-19 pandemic has required significant resources for the treatment of patients affected by the disease in all European countries with serious impact on general and specialist patient care. Additional healthcare burden will be added to restore balance for the treatment of patients with chronic conditions, particularly cardiovascular disease and cancer. The lockdown has put serious strain on the economy and healthcare of European countries. The availability of an integrated and efficient Tele-health network may have helped reducing the negative effects observed during the current pandemic. It is likely that the current trend is going to continue but the issues discussed must be taken into account to maintain a drive to change $[25,26]$.

Telemedicine may have a role to play in the event of out-of-hospital cardiac arrest according to the following survival chain:

1. Early recognition and call for help

2. Early cardiopulmonary resuscitation

3. Early defibrillation

4. Post-resuscitation care

Future developments will see the contribution of our research group to key areas of research as follows:

1. Artificial Intelligence (AI)

2. Telemedicine (support from a distance) 
3. Wearable Devices

4. Simulation

5. E-learning

Studies focusing on the first stage of the survival chain have already led to some AI applications with further solutions potentially available in a non distant future in relation to support from a distance. As far as "Wearable Devices" is concerned, the development of a T-shirt with different sensors integrated in its material would allow patient's mobility without fear of losing the transmission signal.

Our "Telecardiology \& Clinical Application of Numerical Modelling of Biological Systems" research unit based at the National Institute for Cardiovascular Research (Bologna, Italy) is quite active in Simulation and E-learning applications [27-29]. More specifically, we are developing numerical models of the cardiovascular system for trend evaluation of key parameters usually requiring invasive measurement. The aim is the reduction of complications in elderly patients and/or neonates.

Our models allow simulation and evaluation of the effect of drug administration on haemodynamic and energetic parameters. The integration of these models into a simulation software with particular reference to a telecardiology platform will allow long-distance training of medical professionals, paramedics, medical students and residents [30-33].

CARDIOSIM $^{\odot}[28,29,34]$ remains our main platform simulation software of the cardiovascular system, where different numerical models are available to simulate mechanical ventilation and circulatory support [34-36]. Further integration with a telecardiology set up will help clinicians with treatment optimisation of critical heart failure patients [37-40].

\section{Conclusion}

We have been forced to adapt and be more resourceful during the ongoing pandemic. Therefore, we should give serious thoughts to reconsider our current working patterns towards a more beneficial and cost-effective way of living and working.

\section{Funding}

The authors did not receive any funding for this work.

\section{Conflict of Interest}

The authors declare no conflict of interest. 


\section{References}

1. World Health Organization, Regional Office for Europe. Strengthening the Health Systems Response to COVID-19. Technical guidance \#1 "Maintaining continuity of essential health care services while mobilizing the health workforce for COVID-19 response" (1 April 2020).

2. Sarhan F. Telemedicine in healthcare 1: exploring its uses, benefits and disadvantages. Nursing Times 2009; 105(42): 10-13.

3. McLean S, Protti D, Sheikh A. Telehealthcare for long term conditions. BMJ 2011; 342: 374378.

4. Segrelles-Calvo G, Chiner E, Fernández-Fabrellas E. Acceptance of Telemedicine Among Healthcare Professionals. Arch Bronconeumol 2015; 51(12): 611-612.

5. Williams OE, Elghenzai S, Subbe C, Wyatt JC, Williams J. The use of telemedicine to enhance secondary care: some lessons from the front line. Future Healthcare J 2017; 4(2): 109-114.

6. Wang X, Zhang Z, Zhao J, Shi Y. Impact of Telemedicine on Healthcare Service System Considering Patients' Choice. Discrete Dyn Nature Soc 2019; https://doi.org/10.1155/2019/7642176.

7. Hashiguchi O, Bringing T. Health care to the patient: An overview of the use of telemedicine in OECD countries. OECD Health Working Papers, No. 116, OECD Publishing, Paris (2020).

8. Mueller B. Telemedicine Arrives in the U.K.: "10Years of Change in One Week". The New York Times 4th April 2020, updated 7th April 2020.

9. Taylor P. Free telemedicine service in UK will connect patients to at-home doctors. Pharma Phorum 1st April 2020.

10. http://techweb.kingston.ac.uk

11. Telemedicine Forum, Royal Soc. Med., London, U.K. Available HTTP: http://www.qub.ac.uk/telemed/tmed

12. Hex N, Tuggey J, Wright D, Malin R. Telemedicine in care homes in Airedale, Wharfedale and Craven. Clinical Governance: An International Journal 2015; 20: 146-154.

13. Pisanelli DM, Ricci FL, Maceratini R. A Survey of Telemedicine in Italy. Journal of Telemedicine and Telecare. 1995; 1, 125-30.

14. Siwicki B. Telemedicine during COVID-19: Benefits, limitations, burdens, adaptation. Healthcare IT News 19th March 2020.

15. Sommer JT. Telemedicine: A useful and necessary tool to improve quality of health care in the European Union. Comput Methods Programs Biomed 1995; 48: 73-74.

16. Laxminarayan SN, Coatrieux JL, Roux JC, Finklestein SM, Shakian AV, Blanchard SM. Biomedical information technology: Medicine and health care in the digital future. IEEE Trans Inform Technol Biomed 1997; 1: 1-7.

17. Istepanian RH. Telemedicine in the United Kingdom: Current Status and Future Prospects. IEEE Trans Inform Technol Biomed 1999; 3(2): 158-159. 
18. Snell M. 5 Ways Telehealth Is Taking Modern Healthcare to the Next Level. Health Tech Magazine 1st April 2019.

19. Alotaibi S, Hernandez-Montfort J, Ali OE, El-Chilali K, Perez BA. Remote monitoring Alotaibi S, Hernandez-Montfort J, Ali OE, El-Chilali K, Perez BA. Remote monitoring of implantable cardiac devices in heart failure patients: a systematic review and meta-analysis of randomized controlled trials. Heart Fail Rev 2020; 25: 469-479.

20. Ozanne EM, Noseworthy PA, Cameron KA, Schmidt M, Cavanaugh K, Pershing ML, Guzman A, Sivly A, Fagerlin A. Shared Decision Making in the Era of Telehealth: Implications for Practice and Research. MDM Policy Pract 2020; 5(2): 2381468320976364.

21. Bashshur RL, Reardon TG, Shannon GW. Telemedicine: A New Health Care Delivery System. Annu Rev Public Health 2000; 21: 613-637.

22. McNicholas J. TeleHealth in the Modern Era of Military Medical Consultation. MILITARY MEDICINE 2018; 183(5/6): 110-112.

23. Bhaskar S, Bradley S, Chattu VK, Adisesh A, Nurtazina A, Kyrykbayeva S, Sakhamuri S, Yaya S, Sunil T, Thomas P, Mucci V, Moguilner S, Israel-Korn S, Alacapa J, Mishra A, Pandya S, Schroeder S, Atreja A, Banach M, Ray D. Telemedicine Across the Globe-Position Paper from the COVID-19 Pandemic Health System Resilience PROGRAM (REPROGRAM) International Consortium (Part 1). Front Public Health 2020; 8: 556720.

24. Monaghesh E, Hajizadeh A. The role of telehealth during COVID-19 outbreak: a systematic review based on current evidence. BMC Public Health 2020; 20: 1193.

25. Kichloo A, Albosta M, Dettloff K, Wani F, El-Amir Z, Singh J, Aljadah M, Chakinala RC, Kanugula AK, Solanki S, Chugh S. Telemedicine, the current COVID-19 pandemic and the future: a narrative review and perspectives moving forward in the USA. Fam Med Com Health 2020; 8: e000530.

26. Shachar C, Engel J, Elwyn G. Implications for Telehealth in a Postpandemic Future. Regulatory and Privacy Issues. JAMA 2020; 323(23): 2375-2376.

27. Capoccia M, De Lazzari C. Concepts, Mathematical Modelling and applications in heart failure. Capoccia M and De Lazzari C Eds. New York: Nova Science Publisher. (ISBN: 978-153614-771-1).

28. De Lazzari C, Stalteri D. CARDIOSIM Software Simulator Website 2011. https://cardiosim.dsb.cnr.it/

29. De Lazzari C, Pirckhalava M. Cardiovascular and Pulmonary Artificial Organs: Educational Training Simulators. 2017, De Lazzari C, Pirckhalava M Eds. Published by Consiglio Nazionale delle Ricerche (CNR) Roma (ISBN 978-88-8080-240-2), 161-181.

30. De Lazzari C, De Lazzari B, Genuini I, Pirckhalava M. The Use of e-Learning for Healthcare Professionals: an Interactive in Silico Simulator. In Cardiovascular and 
31. Pulmonary Artificial Organs: Educational Training Simulators. 2017, De Lazzari C, Pirckhalava M Eds. Published by Consiglio Nazionale delle Ricerche (CNR) Roma (ISBN 978-888080-240-2), 161-181.

32. De Lazzari C, Pirckhalava M. Simulation in Medicine: Clinical Teaching and Learning. Cardiology and Internal Medicine XXI 2015; 14: 28-30.

33. De Lazzari C, Genuini I, Pisanelli DM, D'Ambrosi A, Fedele F. Interactive simulator for eLearning environments: a teaching software for health care professionals. BioMedical Engineering OnLine 2014; 13(1); 1-18.

34. De Lazzari B, Iacovoni A, Mottaghy K, Capoccia M, Badagliacca R, Vizza CD, De Lazzari C. ECMO Assistance During Mechanical Ventilation: Effects Induced on Energetic and Haemodynamic Variables. Computer Methods and Programs in Biomedicine 2021; 202: 1-13. https://doi.org/10.1016/j.cmpb.202.106003

35. De Lazzari C, De Lazzari B, Iacovoni A, Marconi S, Papa S, Capoccia M, Badagliacca R, Vizza CD. Intra-Aortic Balloon Counterpulsation Timing: A New Numerical Model for Programming and Training in the Clinical Environment. Computer Methods and Programs in Biomedicine 2020; 194: 1-9. https://doi.org/10.1016/j.cmpb.2020.105537

36. De Lazzari C, Darowski M, Ferrari G, Clemente F, Guaragno M. Ventricular energetics during mechanical ventilation and intraaortic balloon pumping - Computer simulation. Journal of Medical Engineering \& Technology, 2001; 25-(3): 103-111.

37. De Lazzari C, Darowski M, Ferrari G, Pisanelli DM, Tosti G. The impact of rotary blood pump in conjunction with mechanical ventilation on ventricular energetic parameters: Numerical Simulation. Methods of Information in Medicine 2006; 45-(5): 574-583.

38. De Lazzari C, Capoccia M, Marconi S. How can LVAD support influence ventricular energetics parameters in advanced heart failure patients? A retrospective study .Computer Methods and Programs in Biomedicine 2019; 172: 117-126.

\section{https://doi.org/10.1016\%2Fj.cmpb.2019.02.012}

39. Capoccia M, Marconi S and De Lazzari C. Decision-making in advanced heart failure patients requiring LVAD insertion: Can preoperative simulation become the way forward? A case study. Journal of Biomedical Engineering and Informatics 2018; 4(2): 8-20.

https://doi.org/10.5430/jbei.v4n2p8

40. Capoccia M, Marconi S, Singh SA, Pisanelli DM and De Lazzari C. Simulation as a preoperative planning approach in advanced heart failure patients. A retrospective clinical analysis. BioMedical Engineering OnLine 2018; 17 (1): 52.

https://doi.org/10.1186/s12938-018-0491-7 


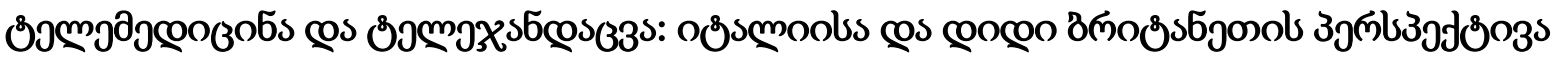

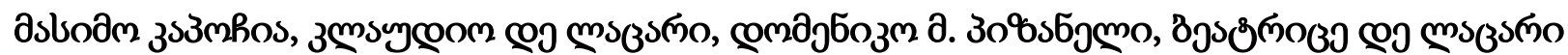

Corresponding Author: Prof. Claudio De Lazzari, C.N.R., Institute of Clinical Physiology, U.O.S. of Rome, Italy, Via Palestro 32, 44, 00185 Rome, Italy

Fax: +390649936299

E-mail: claudio.delazzari@ifc.cnr.it

\section{söbலిmsjōo}

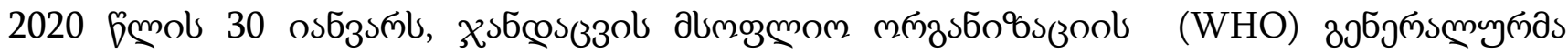

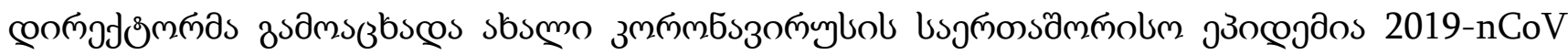
(International Health Emergency of International Concern-PHEIC), зuбдmoлmmöols

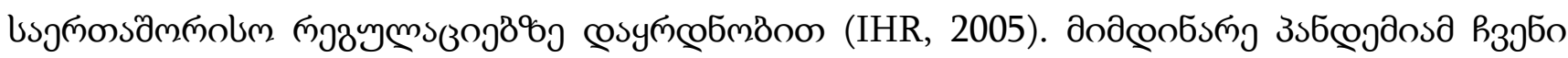

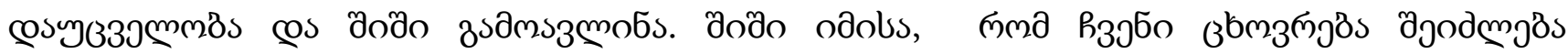

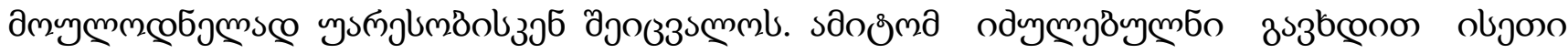

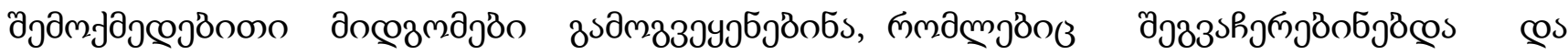

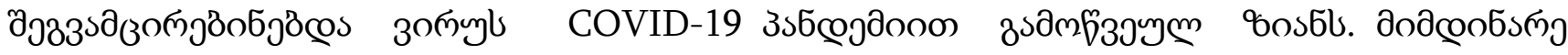

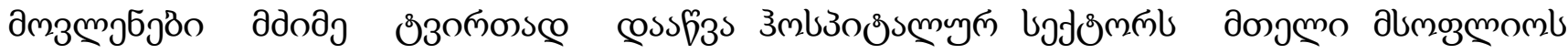

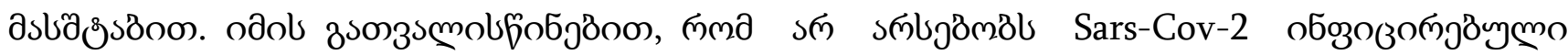

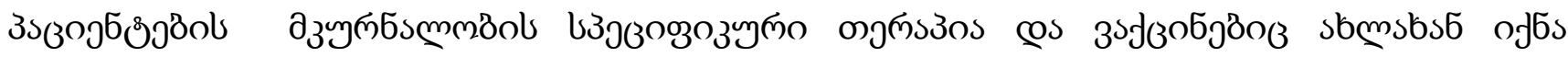

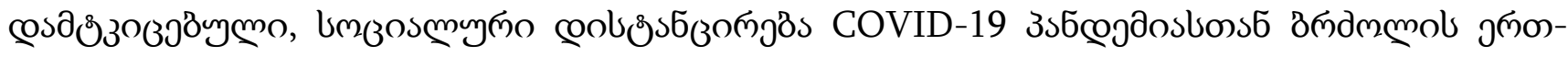

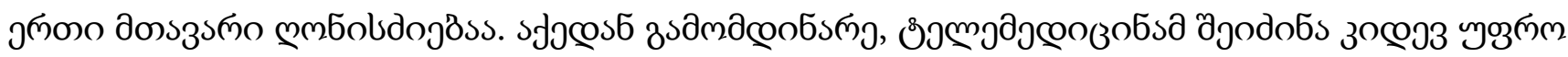

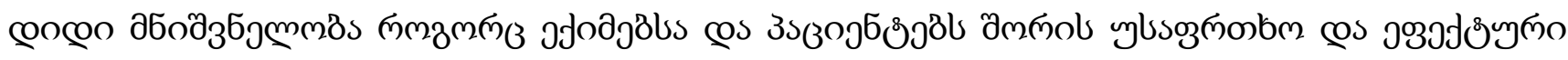

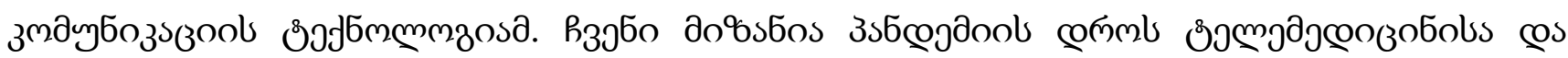

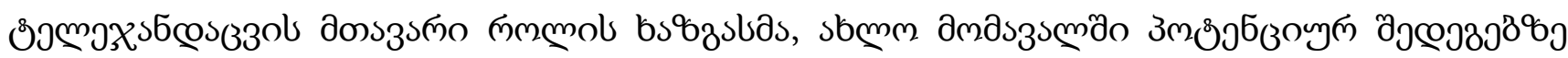

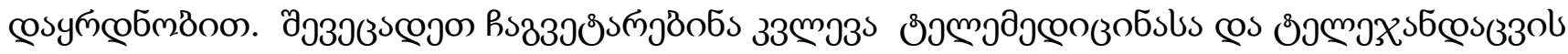

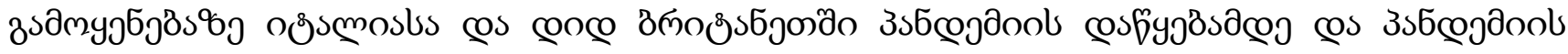

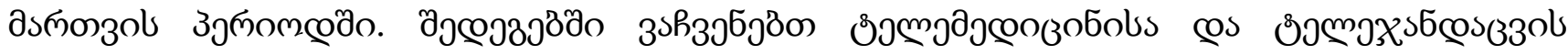

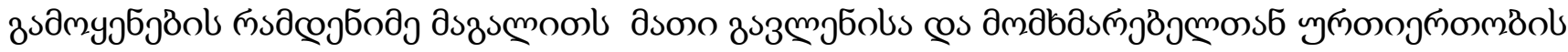
ajlusbjo.

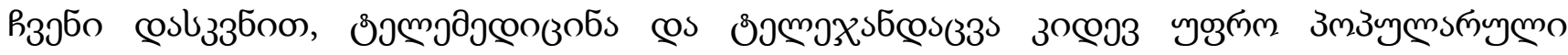

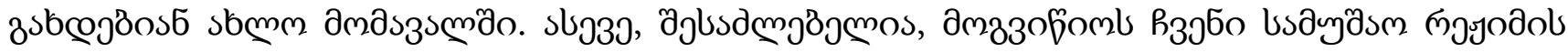

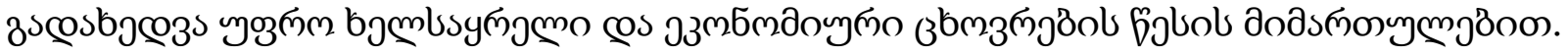

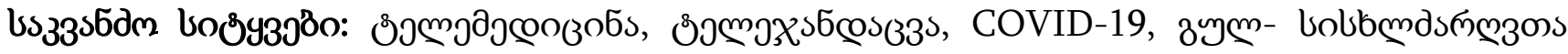
cosszscojojón. 


\section{Телемедищина и телездравоохранение: перспектива Италии и Великобритании}

\section{Массимо Капочиа, Клаудио Де Лащцари, Доменико М. Пизанелли, Беатрис Де Лаццари}

Corresponding Author: Prof. Claudio De Lazzari, C.N.R., Institute of Clinical Physiology, U.O.S. of Rome, Italy, Via Palestro 32, 44, 00185 Rome, Italy

Fax:+390649936299 E-mail: claudio.delazzari@ifc.cnr.it

\section{Абстракт}

30 января 2020 г. Генеральный директор Всемирной организации здравоохранения (ВО3) объявил о международной вспышке нового коронавируса 2019-nCoV (чрезвычайная ситуация в области общественного здравоохранения, имеющая международное значениеPHEIC),как это закреплено в Международных медико-санитарных правилах (ММСП, 2005 г.).

Текущая пандемия выявила нашу уязвимость и страхи, перевернувшие нашу жизнь с ног на голову. Мы были вынуждены использовать более изобретательный подход с целью сдерживания и ограничения потенциального ущерба.Текущие события стали серьезным бременем для больничных организаций по всему миру.

В то время, когда из-за отсутствия специфической терапии для лечения кардиологических пациентов и вакцины, одобренной только недавно, социальное дистанцирование является одной из основных мер, используемых для борьбы с пандемией COVID-19, телемедицина получает все большее распространение как ключевая технология для безопасной и эффективной общение между врачами и пациентами. Цель состоит в том, чтобы подчеркнуть важную роль телемедицины и телездравоохранения во время пандемии с указанием потенциальных последствий в обозримом будущем.

Мы попытались провести обзор приложений телемедицины и телездравоохранения в Италии и Великобритании до и во время борьбы с пандемией. Были выделены некоторые примеры применения телемедицины и телездравоохранения с учетом их воздействия и взаимоотношений с конечными пользователями.

Телемедицина и телездравоохранение, вероятно, станут более популярными в будущем. Возможно, нам придется пересмотреть наши текущие модели работы в направлении более выгодного и экономичного образа жизни и работы.

Ключевые слова: телемедицина, телездравоохранение, COVID-19, сердечно-сосудистые заболевания. 